Research article

\title{
Taxonomic account of an Indian endemic, monotypic genus Adenoon Dalzell with a note on lectotypification of Adenoon indicum Dalzell
}

\author{
Bandana Bhattacharjee $^{1 *}$, Sobhan Kumar Mukherjee ${ }^{2}$ and P. Lakshminarasimhan ${ }^{3}$ \\ ${ }^{1}$ Central National Herbarium, Botanical Survey of India, Howrah-711103, West Bengal, India \\ ${ }^{2}$ Department of Botany, University of Kalyani, Kalyani-741235, West Bengal, India \\ ${ }^{3}$ Botanical Survey of India, Western Regional Centre, 7-Koregaon Road, Pune-411001, Maharashtra, India
}

*Corresponding Author: bandanabsi@rediffmail.com

[Accepted: 11 December 2016]

\begin{abstract}
The genus Adenoon is endemic to India with its only species A. indicum distributed in Western Ghats of Goa, Maharashtra, Karnataka, Kerala and Tamil Nadu. A taxonomic account of the genus is provided here along with detailed descriptions and photo-plates and a lectotype is designated for $A$. indicum to fix the application of the name.
\end{abstract}

Keywords: Asteraceae - Endemic - Monotypic - Vernonieae - Lectotype.

[Cite as: Bhattacharjee B, Mukherjee SK \& Lakshminarasimhan P (2016) Taxonomic account of an Indian endemic, monotypic genus Adenoon Dalzell with a note on lectotypification of Adenoon indicum Dalzell. Tropical Plant Research 3(3): 649-653]

\section{INTRODUCTION}

The genus Adenoon Dalzell (Asteraceae: Cichorioideae: Vernonieae) was described by Dalzell (1850) with a single species A. indicum Dalzell. The genus is characterized by herbaceous (perennial) habit, alternate, sessile leaves with ovate to obovate-elliptic lamina and irregularly serrated margins, homogamous heads with long peduncles in terminal corymbose panicles, purple florets devoid of pappus, terete to narrowly oblong-ovoid strongly 10-ribbed achenes. The genus is monotypic as any other species under the same is yet to be described.

\section{MATERIALS AND METHODS}

The present communication is a part of the revisionary study on the tribe Vernonieae Cass. for 'Flora of India' scheme of Botanical Survey of India which is mainly based on thorough scrutiny of authentic literature (including protologue), the study of herbarium specimens (including types) deposited at various Indian as well as foreign herbaria and study of live-specimens collected during the field surveys. Morphological details of the specimens are critically observed under 'Olympus SZ-51' dissecting microscope. Flowers from fresh collections and herbarium/dry specimens are dissected for drawing descriptions and preparation of photo-plate. After completion of the study, the collected specimens are poisoned, pressed, mounted on standard herbarium sheets and deposited at CAL with field-data written on the herbarium-labels for future reference.

\section{RESULTS}

Taxonomic account of the genus Adenoon Dalzell:

Adenoon Dalzell in Hooker's J. Bot. Kew Gard. Misc. 2: 344. 1850; Benth. in Benth. \& Hook. f., Gen. Pl. 2(1): 170. 1873; C.B. Clarke, Compos. Ind. 5. 1876; Hook. f., Fl. Brit. India 3: 229. 1882; Uniyal in Hajra \& al. (eds.), Fl. India 13: 331. 1995; H. Rob. in Kubitzki (ed.), Fam. Gen. Vas. Pl.: 171. 2007.

Type: Adenoon indicum Dalzell

Erect, terrestrial, rigid, perennial herbs. Stem simple below, branched above, angled, grooved, scabrous, hairy. Leaves alternate, sessile; lamina ovate to obovate-elliptic, margins irregularly serrated. Heads in corymbose panicles, homogamous, long-pedunculate, bractetate at the forks and below the head. Involucre campanulate; phyllaries numerous. Florets actinomorphic, purple. Pappus absent. Corolla slender, tubular, limbs 
narrowly 5-cleft. Anther-base sagittate, shortly tailed. Style branched at apex, arms subulate, hairy. Achenes terete to narrowly oblong-ovoid, subcompressed, with numerous glands on wall, 10-ribbed.

Distribution: The genus is monotypic and endemic to India (Goa, Maharashtra, Karnataka, Kerala, Tamil Nadu).

Etymology: The name of the genus is derived from the Greek words 'aden' (glands), because of the presence of numerous glands in between the ridges of the achene wall.

Adenoon indicum Dalzell in Hooker's J. Bot. Kew Gard. Misc. 2: 344. 1850; Dalzell \& A. Gibson, Bombay Fl.: 121. 1861; Hook. f., Fl. Brit. India 3: 229. 1881; T. Cooke, Fl. Bombay 2: 9. 1904; Gamble, Fl. Madras 2: 668. 1921; B.D. Sharma \& al., Fl. Karnataka Anal.: 134. 1984; V. Chandrasekaran in A.N. Henry \& al. (eds.), Fl. Tamil Nadu India Anal. 2: 28. 1987; R.R. Rao \& al., Fl. Ind. Enum. Asterac.: 1. 1988; S.D. Deshp. \& al., Fl. Mahabaleshwar 1: 299. 1993; Sivar. \& P. Mathew, Fl. Nilambur: 357. 1997; M.R. Almeida, Fl. Maharashtra 3A: 66. 2001; Singh \& al. (eds.), Fl. Maharashtra St. 2: 180. 2001; T.S. Nayar \& al., Flow. Pl. Kerala: 98. 2006; Karthik. \& al., Fl. Pl. India Dicot. 1: 241. 2009.

Types: Bombay, Dalzell s.n. [lectotype, designated here: K (K000814618), photo! (Fig. 1)]; Mihi?, 'Ex Herb Dr Stocks', Dalzell s.n. [syntype: K (K000814616), photo!].

Vernacular/Common names: Blue Sonki, Motha Sonki, Dhuni, Kusamb

Erect, terrestrial, rigid, perennial herbs, $25-50 \mathrm{~cm}$ tall. Stem simple below, branched above, angled, grooved, scabrous, pubescent, hairs simple, multiseptate. Leaves alternate, sessile; lamina ovate to obovate-elliptic, 1-10 $\times 0.5-6.5 \mathrm{~cm}$, light green above, pale beneath, margins irregularly serrate, serrations ending in mucro, acute to short-mucronate at apex, trinerved, prominently nerved beneath, scabrous, with thick hairs on both sides, hairs articulated, glandular. Heads 1-1.5 cm across with purple florets; peduncle up to $10 \mathrm{~cm}$ long; bracts oblonglinear-lanceolate, cartilaginous, mucronate, rough, trinerved, hirsute, hairs jointed, glandular. Phyllaries numerous, 4-5-seriate, 2-6 × 1.0-2.2 mm, imbricate, glandular hairy on the back, ciliate on the margins in the upper half, outer shorter, oblong-lanceolate to ovate-lanceolate, progressively increasing in length, inner oblongelliptic, thinner. Florets up to 50, purple. Pappus absent. Corolla regular, slender, tubular, limbs narrowly 5cleft, each ca. $2.0 \times 0.5 \mathrm{~mm}$, tube 5-6 mm long. Anthers $c a .3 \mathrm{~mm}$ long, base sagittate, shortly tailed; filaments 1.5-2.0 mm long. Style 9-11 mm long, base with ca. $0.5 \mathrm{~mm}$ long knob like structure, bifid at apex, arms $1.5-$ $2.0 \mathrm{~mm}$ long bearing stigmatic surfaces, subulate, hairy. Achenes terete to narrowly oblong-ovoid with obtuse ends, 2-3 $\times 0.7-1.2 \mathrm{~mm}$, subcompressed, glabrous, 10-ribbed, ribs very stout, glandular between ribs.

(Fig. 2)

Flowering \& Fruiting: August-April.

Habitat: Common in open forest areas.

Distribution: INDIA (Goa, Maharashtra, Karnataka, Kerala, Tamil Nadu); Endemic.

Etymology: The species was named after 'India', the country from where the types were collected.

Specimens examined: INDIA, Goa, Castle Rock, ca. 610 m, October 1908, A. Meebold 9863 (CAL). Karnataka, Coorg district, Brahmagiri hill slope, ca. 1372 m, 30.11.1976, T.A. Rao \& B.C. Banerjee 11669 (CAL); Chikkamagaluru district, Kulhutty, Bababoodan, ca. 1220-1524 m, October 1908, A. Meebold 9403 (CAL); Chikkamagaluru, Bidertallu?, Mudigere, 18.10.1965, R.K. Arora 5069 (CAL); Dakshina Kannada, South Cauasa ghats, 1873, R.H. Beddome (MH); Mysore district, Megarvalli, Agumbe, 14.02.1961, R.S. Raghavan 68161 (CAL); Uttara Kannada district, Thiai Ghant?, 15.09.1891, W.A. Talbot 2518 (CAL). Kerala, Wayanad district, Brahmagiri, ca. 1220-1585 m, 05.12.1907, C.E.C. Fischer 185 (CAL); Brahmagiri, $1000 \mathrm{~m}$, 08.04.1988, C. Ramesan 41348 (CALI); 900 m, September 1988, C. Ramesan 41348 (CALI); Kottayam, Ithithassum, Changanacheday, 25 m, 04.02.1984, V.T. Antony 262 (MH). Maharashtra, Kolhapur district, Kondosh, 27.09.1998, S.R. Yadav 5817 (SUK); Kondosh, M.M. Sardesai 613 (SUK); Satara District, Mahabaleshwar, T. Cooke 88 (CAL); March 1883, T. Cooke s.n. (CAL); Mahabaleshwar, T. Cooke 105 (CAL); Mahabaleshwar, T. Cooke s.n. (MH); Mahabaleshwar, Niwar, Fitzerald Ghat?, c. 1067 m, 29.12.1950, P.V. Bole 220 (CAL); Kas, October 1992, M.P. Bachulkar \& Cholekar 5459 (SUK); Mahabaleshwar, V.D. Vartak s.n. (AHMA); Mahabaleshwar, 29.10.13, B. Bhattacharjee 62150, 62151, 62152 (CAL); Sindhudurg district, Amboli area, 30.11.1982, K. Kulkarni 27370 (AHMA); Amboli, 650 m, October 2012, S. Raskar s.n. (CAL); Thane district: Thane, Sadsya Ghat top, Tok Range, 16.11.1968, K.V. Billore 115455 (CAL); Thane, Kedarnath hill slope, Takavada Range, 16.11.1968, K.V. Billore 115487 (CAL); Without precise locality, 'Concan', Dr. Stocks 140 [P (P02837341, P02837342, P02837343), photo!)]. 


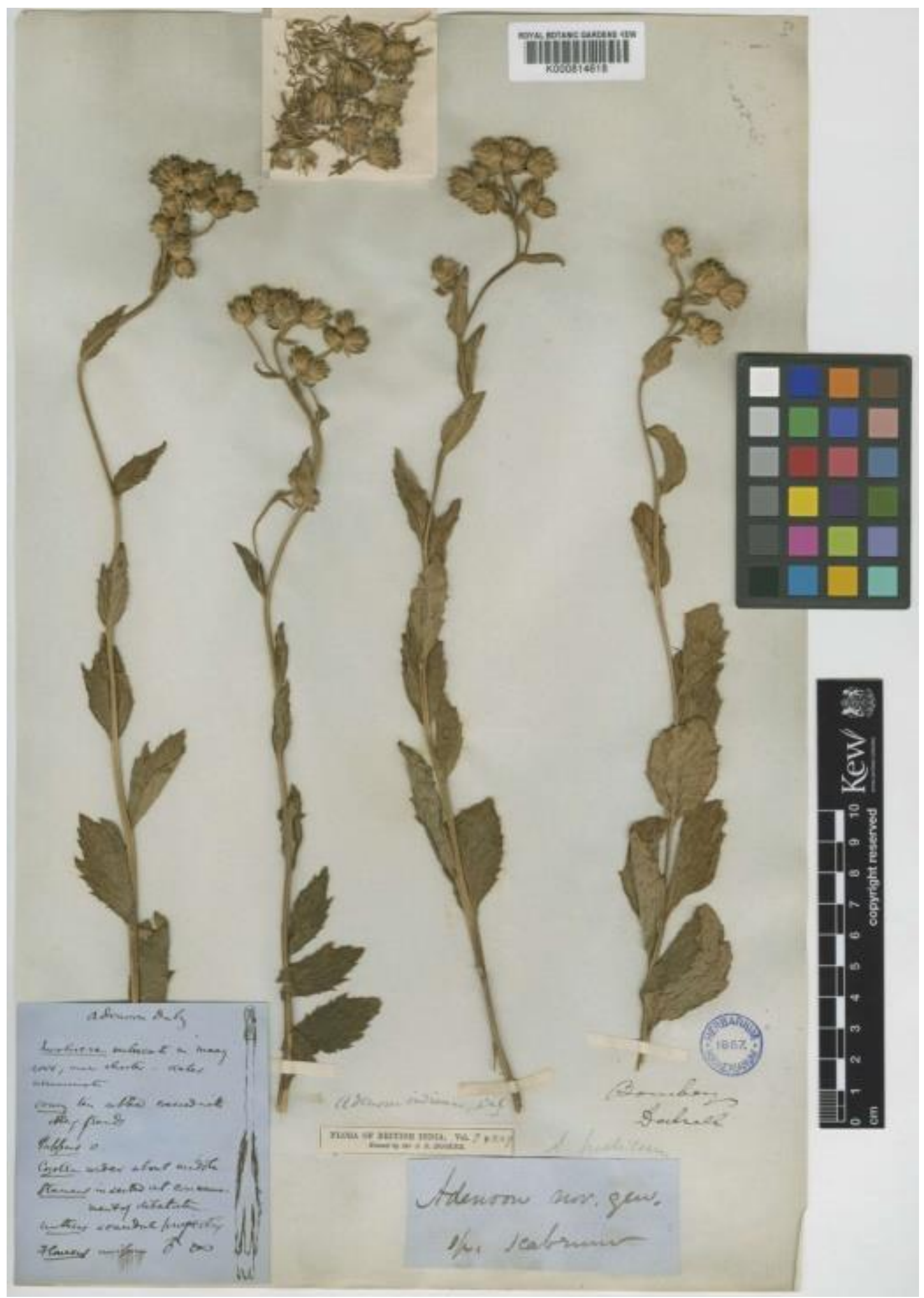

Figure 1. Adenoon indicum Dalzell: Lectotype (K000814618) [@ copyright of the Board of Trustees of the Royal Botanic Gardens, Kew] 




Figure 2. Adenoon indicum Dalzell: A, Habit; B, Heads; C, Involucre; D, Phyllaries; E, Floret; F, Gynoecium; G, Close-up of ovary; H, Close-up of style apex; I, Stamens; J, Achenes [Prepared from 'B. Bhattacharjee 62150' (CAL) before mounting]. 


\section{Note on lectotypification of Adenoon indicum Dalzell:}

While describing A. indicum, Dalzell (l.c.) mentioned that the plants were collected from 'Phonda Ghaut, Syhadree' which flowered in September. He further mentioned - "Every part of this plant, including corolla and anthers, is covered with white, smooth, oval glands, like the eggs of some insects". Two specimens of $A$. indicum collected by Dalzell were traced at $\mathrm{K}$ and both of these were indicated as 'nov. gen.' by Dalzell. The precise locality of collections, date of collection etc. are not provided on the label-data of these specimens. However, Dalzell provided a crude description and an illustration of a single floret in a separate label which was mounted on a K-specimen (K000814618). Further, Dalzell wrote 'sp. scabrum' and 'Bombay' on the same sheet. All these informations provided in K-specimen (K000814618) clearly indicate that this particular specimen was emphasized by Dalzell while describing A. indicum. Therefore, the K-specimen (K000814618) is selected here as lectotype of A. indicum according to Art. 9.2 of ICN (McNeill et al. 2012) which also in full agreement with the description provided in the protologue. The specimens ' $D r$. Stocks 140 ' presently deposited at P (studied by J.D. Hooker) were not examined by Dalzell while describing A. indicum and thus not considered as 'original material'. Two more specimens were traced at CAL and as per the label-data these specimens were purchased from Dalzell's herbarium in 1878 ('Herb. of N. Dalzell Bombay: purchased 1878'). However, collection locality, date of collection and name of the collector were not written on the labels/sheets. Further, there is no indication that Dalzell studied these specimens before publishing A. indicum. Therefore, these two CAL-specimens, which most probably postdate the protologue of $A$. indicum, are also not considered as 'original material' of A. indicum.

\section{ACKNOWLEDGEMENT}

The authors are thankful to Dr. Paramjit Singh, Director, Botanical Survey of India (BSI), Kolkata for providing research facilities.

\section{REFERENCES}

Dalzell NA (1850) Contribution to the Botany of Western India. Hooker's Journal of Botany and Kew Garden Miscellany 2: 336-344.

McNeill J, Barrie FR, Buck WR, Demoulin V, Greuter W, Hawksworth DL, Herendeen P, Knapp S, Marhold K, Prado J, Prud'homme Van Reine WF, Smith GF, Wiersema JH \& Turland NJ (eds) (2012) International Code of Nomenclature for algae, fungi, and plants (Melbourne Code): Adopted by the Eighteenth International Botanical Congress Melbourne, Australia, July 2011. Regnum Vegetabile 154. Königstein: Koeltz Scientific Books, 140 pp. 